\title{
Hand washing as an effective technique for intestinal parasites control among school children in Gaza city
}

\author{
Adnan Alhindi ${ }^{1^{*}} \mid$ Moeen Alkarirri ${ }^{2} \mid$ Basil Kanoa $^{3} \mid$ Samaher S Abu Ouda ${ }^{4}$ Yasmeen \\ M Erqyq ${ }^{5} \mid$ Amal I Radwan ${ }^{6} \mid$ Marwan O Jalambo $^{7}$
}

${ }^{1}$ Medical Laboratory Sciences Department, Faculty of Health Sciences, Islamic University of Gaza, P.O. Box, 108, Gaza, Palestine

${ }^{2}$ Health Education and Health promotion Department, Ministry of Health, Gaza, Palestine

${ }^{3}$ Ministry of Health, Gaza, Palestine

4,5,6 Medical Laboratory Sciences Medical Laboratory Sciences Department, Faculty of Health Sciences, Islamic University of Gaza, P.O. Box, 108, Gaza, Palestine

${ }^{7}$ Nutrition Sciences and Public Health Program, Palestine Technical College, Gaza, Palestine

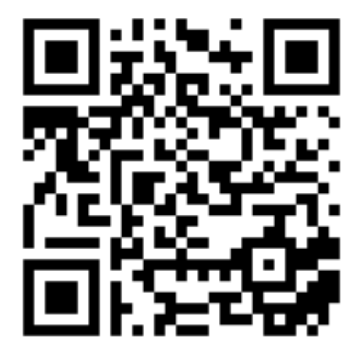

\begin{abstract}
Background/aim: Hand washing is one of the most effective ways to prevent the spread of many types of infection and illness especially those spread through oral-fecal route. Intestinal parasites are parasites that populate the gastrointestinal tract in humans and other animals they can live throughout the body, but most prefer the intestinal wall. Intestinal parasitic infections are among the most common infections worldwide. The high prevalence of parasites infection in children is attributed to many factors, particularly environmental and personal hygiene

We aimed to assess the using of hand washing technique for the controlling of intestinal parasites infection among school children in Gaza.

Method: 508 children from primary school children were examined for the presence of intestinal parasites and then the infected children were divided into case and control groups based on match criteria. Hand washing and health education were applied on intervention group and then the second stool sample was examined from both case and control groups. Results: the prevalence of intestinal parasitic among school children was $23.2 \%$. Entamoeba histolytica/dispar was the highest protozoa detected among school children in this study (73.3\%). The prevalence of intestinal parasites among children was reduced after the application of hand washing technique from $23.2 \%$ to $15.5 \%$, the prevalence of intestinal parasites in male higher than female due to variant behaviour of both sexes. Conclusion: It is concluded that hand washing has a significant role in reducing intestinal parasitic infection among school children. It is recommended that hand washing should be delivered to all school children in Gaza strip.
\end{abstract}

Key words: Hand washing; Intestinal parasites; school children; Gaza city

Copyright : (C) 2021 The Authors. Published by Medical Editor and Educational Research Publishers Ltd. This is an open access article under the CC BY-NC-ND license

(https://creativecommons.org/licenses/by-nc-nd/4.0/). 


\section{1 | INTRODUCTION}

7 he global burden of disease associated with poor water, sanitation, and hygiene (WASH) is concentrated among children and thus promoting the practice of handwashing with soap (HWWS) among children presents an important public health measure (1). The importance of thorough hand washing for protection against various forms of communicable disease has been known since early recorded history (2). Intestinal parasitic infections are among the most common infections worldwide (3). Population behavior may be the main cause of a health problem, but it can also be the main solution (4). The high prevalence of parasites infection in children is attributed to many factors, particularly environmental and personal hygiene (5). Despite the improvement of infrastructure of Gaza Strip the existence of intestinal parasitic diseases (IPD) in Gaza strip is still constituting a health problem and was approved by many studies and the general prevalence was ranged between 20-40\% (6-7). Many studies about IPD have been carried out among school-age and preschool children either in Gaza Strip (8).

The current study aims to assess the prevalence of intestinal parasites infection among school children in Gaza, and to investigate the effectiveness and the the impact of hand washing technique on the prevalence of intestinal parasites among school children in Gaza.

\section{2 | MATERIALS AND METHODS}

\section{1 | Ethical considerations}

Ethical approval was obtained from the Ministry of Education and a consent form was obtained from each child parents.

\subsection{Selection criteria of children}

The age of children rank was: 9 to 12 years old and to be resident in Gaza city.

\section{3 | Sample size/period of study}

the number of population of children in the age group from 9- 12 years old was estimated to be 30,827 (Ministry of Education, 2012). So the sample size to be taken was 618 (response is $82.2 \%$ ). The present study has started from Sep, 2012 to June 2013. The first step was using school selection phase from Gaza city. From 117 school it was selected 5 schools. The second step was using class selection phase from these schools. From 827 classes it was selected 17 classes based on systematic random selection technique. Then the required sample was taken from selected classes (each child from each selected classes).

Each child who was participating in the study was advised to give one stool sample in a clean container in the early morning in the first exam.

\section{4 | Questionnaire}

All participants were interviewed, and information was arranged in special form which includes: General information (name, age, sex, residence, number of rooms, family members, education level of parents), environmental health (drinking water source, type of sewage system, garbage around home). Clinical symptom (loss of weight, loss of appetite, anorexia, abdominal pain, diarrhea, constipation) and health habits. All necessary information regarding the different aspects of the research such as the objectives, sampling method, assay procedure, and free laboratory testing was fully explained to the parents to obtain their agreement for their children participation.

Supplementary information The online version of this article (https://doi.org/10.52845/JMRHS/20214-11-7) contains supplementary material, which is available to authorized users.

Corresponding Author: Prof. Dr. Adnan Alhindi Medical Laboratory Sciences Department, Faculty of Health Sciences, Islamic University of Gaza, P.O. Box, 108, Gaza Palestine 


\section{5 | Parasitological analysis}

Stool specimens were analysed using direct saline film and formal-ether concentration technique were used according to WHO protocols (9). The same microscope was used in all sample examination. Eyepiece micrometer was used to measure the exact size of each protozoa detected. Each examined slide was placed in dettol to prevent distribution of the infection.

\section{6 | Treatment of infected children}

Each child infected with intestinal parasites was given the appropriate drug (under the supervision of a physician) and guidance paper for parents to how to give therapy for their children.

\section{7 | Intervention-control groups}

A group of infected school children with intestinal parasites were divided into two groups: Intervention (45 child) and control (45 child) groups. School children were selected in both groups based on match criteria include: (age, sex, standard of living and place of residence).

\subsection{Hand washing technique}

\subsubsection{Activity of control group}

control group was given general health education.

\subsubsection{Activity of intervention group}

A single visit weekly for each school was made; each meeting was 25-30 minutes and was given advanced hand washing technique training and how to wash their hands properly and learning children about health education.

\section{9 | Methods of application of washing hands and health education}

Talk about health was applied for the children in each school. A Lecture for children about the definition of hand washing and its importance and times that must wash their hands. Learning of hand washing using a special WHO chart, video and practical hand washing technique. A lecture on personal hygiene such as hair cleanliness, pruning nails and bathing. A short story about exposed foods where it causes infection. Written material that contained advices and information about intestinal parasite and its transmission. Focus group for children's mothers.

\subsection{0 | Focus group for children's mothers}

Lecture for children's mothers included multiple topics: Personal and environmental hygiene, example of some diseases that related to the low personal hygiene, treatment package, consequences of ignorance and types of intestinal parasites that detected in the stool samples and the importance of attention to the cleanliness of their children.

2.11 Follow up study Those children were monitored weekly to be sure for their commitment for application of hand washing. Designed questionnaire was filled for each child in addition to the checklist. Observation of children about applying hand washing technique. Monitoring weekly for hand washing technique was taken place for four months.

\subsection{1 | Post-test study}

After four months from the application of hand washing technique a second stool sample from each infected child (intervention and control) was collected and examined for the presence of intestinal parasites.

\subsection{2 | Statistical analysis}

Data were analyzed by SPSS version 24 using Chisquare test and regression test to determine the possible correlation between IPI and associated risk factors. A P $<0.05$ was considered statistically significant.

\section{3 | RESULTS}

In the present study, the total sample was 508 school children, the children aged from 9 to 12 years, the number of males is equal to the number of females, 
ALHINDI ET AL.

MEERP LTD

the highest percentage of the study sample (35.4\%) was 11 years old, most of the children was reside in the Gaza city (96.7\%), the results show that the highest percentage of the occupation of the children's fathers was worker (42.3\%) but for children's mothers was homework $(88.0 \%)$, the highest percentage of education level of the children's fathers was primary $(40.2 \%)$ but for children's mothers was secondary $(51.8 \%)$, the most level of income was less than 1000 $(49.6 \%)$.

The most drinking water source was from vendors $(84.6 \%)$, closed sewers is the most type of sewage system (82.1\%), most of the families have no garbage around their homes, most of the children's families do not have agricultural Lands around their homes and most of them do not irrigate their agricultural land with sewage (92.1\%).

hows the most of children have symptoms (52.6\%) and the most children suffering from abdominal pain $(32.3 \%)$ but the least symptom was vomiting (7.3\%).

Table 1: Reported symptoms by children's family

\begin{tabular}{|l|l|}
\hline Variables(n=508) & N $(\%)$ \\
\hline $\begin{array}{l}\text { Symptoms } \\
\text { Yes } \\
\text { No }\end{array}$ & $267(52.6)$ \\
\hline $\begin{array}{l}\text { Vomiting } \\
\text { Yes } \\
\text { No }\end{array}$ & $241(47.4)$ \\
\hline $\begin{array}{l}\text { Diarrhea } \\
\text { Yes } \\
\text { No }\end{array}$ & $37(7.3)$ \\
\hline $\begin{array}{l}\text { Weight loss } \\
\text { Yes } \\
\text { No }\end{array}$ & $471(92.7)$ \\
\hline $\begin{array}{l}\text { Constipation } \\
\text { Yes } \\
\text { No }\end{array}$ & $49(9.6)$ \\
\hline $\begin{array}{l}\text { Abdominal pain } \\
\text { Yes } \\
\text { No }\end{array}$ & $109(21.5)$ \\
\hline $\begin{array}{l}\text { Present of worm } \\
\text { Yes } \\
\text { No }\end{array}$ & $399(78.5)$ \\
\hline $\begin{array}{l}\text { Inflammation of skin } \\
\text { Yes } \\
\text { No }\end{array}$ & $77(15.2)$ \\
\hline $\begin{array}{l}\text { Loss of appetite } \\
\text { Yes } \\
\text { No }\end{array}$ & $131(84.8)$ \\
\hline
\end{tabular}

The most children washing their hands with water and soap after defecation and before eating compared with children who wash their hands with water only, show in table 2 .

Table2: Hand washing technique and health education

\begin{tabular}{|l|l|}
\hline Variables (n=508) & N $(\%)$ \\
\hline $\begin{array}{l}\text { Washing children's hands after defecation with water } \\
\text { Yes } \\
\text { No }\end{array}$ & $\begin{array}{l}41(80.9) \\
97(19.1)\end{array}$ \\
\hline $\begin{array}{l}\text { Washing children's hands after defecation with water and } \\
\text { soap } \\
\text { Yes } \\
\text { No }\end{array}$ & $437(86.0)$ \\
\hline $\begin{array}{l}\text { Washing children's hands before eating with water } \\
\text { Yes } \\
\text { No }\end{array}$ & $71(14.0)$ \\
\hline $\begin{array}{l}\text { Washing children's hands before eating with water and } \\
\text { soap } \\
\text { Yes } \\
\text { No }\end{array}$ & $364(71.7)$ \\
\hline
\end{tabular}

Table 3 shows most of children washing their hands with water and soap in the right way, most children were interesting in personal hygiene (clothes, nails and hair), most children showering two time and more in each week $(42.2 \%)$, most children washing teeth two times per day $(71.1 \%)$, most children were followed and directed by parents $(93.3 \%)$, most children talk to their parents on the subject of personal hygiene and what they have learned (97.8\%).

Table 3: Monitoring children for application of control program

\begin{tabular}{|c|c|}
\hline Variables $(n=45)$ & N $(\%)$ \\
\hline $\begin{array}{l}\text { Washing children's hands with water and soap in the right way } \\
\text { Yes } \\
\text { No }\end{array}$ & $\begin{array}{l}39(86.7) \\
6(13.3)\end{array}$ \\
\hline $\begin{array}{l}\text { Washing children's hands with water and soap before eating } \\
\text { Yes } \\
\text { No }\end{array}$ & $\begin{array}{l}43(95.6) \\
2(4.4)\end{array}$ \\
\hline $\begin{array}{l}\text { Washing children's hands with water and soap after defecation } \\
\text { Yes } \\
\text { No }\end{array}$ & $\begin{array}{l}41(91.1) \\
4(8.9)\end{array}$ \\
\hline $\begin{array}{l}\text { Washing children's hands with water and soap after playing } \\
\text { Yes } \\
\text { No }\end{array}$ & $\begin{array}{l}40(88.9) \\
5(11.1)\end{array}$ \\
\hline $\begin{array}{l}\text { Cleaning children's clothes } \\
\text { Yes } \\
\text { No }\end{array}$ & $\begin{array}{l}44(97.8) \\
1(2.2)\end{array}$ \\
\hline $\begin{array}{l}\text { Pruning children nails } \\
\text { Yes } \\
\text { No }\end{array}$ & $\begin{array}{l}41(91.1) \\
4(8.9)\end{array}$ \\
\hline $\begin{array}{l}\text { Cleaning children hair } \\
\text { Yes } \\
\text { No }\end{array}$ & $\begin{array}{l}44(97.8) \\
1(2.2)\end{array}$ \\
\hline $\begin{array}{l}\text { Showering per week } \\
\text { Once } \\
\text { Twice } \\
\text { More than twice }\end{array}$ & $\begin{array}{l}7(15.6) \\
19(42.2) \\
19(42.2)\end{array}$ \\
\hline $\begin{array}{l}\text { Washing teeth per day } \\
\text { Never } \\
\text { Once } \\
\text { Twice } \\
\text { More than twice }\end{array}$ & $\begin{array}{l}4(8.9) \\
498.9) \\
32(71.1) \\
5(11.1)\end{array}$ \\
\hline $\begin{array}{l}\text { Directing parents of children hygiene } \\
\text { Yes } \\
\text { No }\end{array}$ & $\begin{array}{l}42(93.3) \\
3(6.7)\end{array}$ \\
\hline $\begin{array}{l}\text { Talking children with their parents on the topics of hygiene } \\
\text { Yes } \\
\text { No }\end{array}$ & $\begin{array}{l}44(97.8) \\
1(2.2)\end{array}$ \\
\hline
\end{tabular}


HAND WASHING AS AN EFFECTIVE TECHNIQUE FOR INTESTINAL PARASITES CONTROL AMONG SCHOOL CHILDREN IN GAZA CITY

Table 4 shows that the percentage of children who washing their hands before eating and after defecation was raised after hand washing intervention.

Table 4: Health education before and after hand washing intervention

\begin{tabular}{|llc|}
\hline Variables $(\mathrm{n}=508)$ & \multicolumn{1}{c}{\begin{tabular}{c} 
Before the program \\
\cline { 2 - 3 }
\end{tabular}} & $\begin{array}{c}\text { After the program } \\
(\mathrm{n}=45)\end{array}$ \\
\cline { 2 - 3 } & $\mathrm{N}(\%)$ & $\mathrm{N}(\%)$ \\
\hline Washing children's hands & & \\
Before eating & $392(77.2)$ & $43(95.6)$ \\
After defecation & $437(86.0)$ & $41(91.1)$ \\
\hline
\end{tabular}

The prevalence of intestinal parasitic infection was reduced after hand washing intervention that has statistically significance showed in table 5 .

Table 5: Prevalence of intestinal parasitic infection before and after hand washing technique

\begin{tabular}{|c|c|c|c|c|}
\hline \multirow[b]{2}{*}{ Variables } & $\begin{array}{l}\text { Before } \\
(1 \mathrm{I}=508)\end{array}$ & $\begin{array}{l}\text { After } \\
(\mathrm{n}=90)\end{array}$ & \multirow[t]{2}{*}{$X^{2}$} & \multirow[t]{2}{*}{ P-value } \\
\hline & I $(\%)$ & I $(\%)$ & & \\
\hline $\begin{array}{l}\text { Washing children's hands with water atter } \\
\text { defecation. }\end{array}$ & $102(20.1)$ & $6(14.0)$ & 7.019 & 0.008 \\
\hline $\begin{array}{l}\text { Washing childtren's hands with water and } \\
\text { soap after defecation. }\end{array}$ & $107(21.1)$ & $7(16.3)$ & 5.459 & 0.011 \\
\hline $\begin{array}{l}\text { Washing chilldren's hands with water before } \\
\text { eating. }\end{array}$ & $86(16.9)$ & $3(7.0)$ & 9.029 & 0.002 \\
\hline $\begin{array}{l}\text { Was ling chilldren's hands with water and } \\
\text { soap befooe eating. }\end{array}$ & $95(18.7)$ & $4(9.3)$ & 8.824 & 0.002 \\
\hline
\end{tabular}

The prevalence of intestinal parasite for case and control groups was reduced from $17.7 \%$ to $15.5 \%$ for case group, the most intestinal parasite was Entamoeba histolytica/dipar (73.3\%), the percentage of each type of parasites reduced after hand washing technique this show in table 6.

Table 6: The prevalence of the types of intestinal parasite before and after hand washing technique

\begin{tabular}{|c|c|c|c|}
\hline \multirow{3}{*}{ Variables } & $\begin{array}{c}\text { Before } \\
(\mathrm{n}=508)\end{array}$ & \multicolumn{2}{|c|}{$\begin{array}{c}\text { After } \\
(\mathrm{n}=90)\end{array}$} \\
\hline & & $\begin{array}{c}\text { Case } \\
(\mathrm{n}=45)\end{array}$ & $\begin{array}{c}\text { Control } \\
(\mathrm{n}=45)\end{array}$ \\
\hline & N (\%) & N $(\%)$ & $\mathrm{N}(\%)$ \\
\hline Number of intestinal parasites & $90(17.7)$ & $7(15.5)$ & $9(20)$ \\
\hline \multicolumn{4}{|l|}{ Type of intestinal parasite } \\
\hline Entamoeba histolyticaldispar & $66(73.3)$ & $5(11.1)$ & $5(11.1)$ \\
\hline Giardia lamblia & $14(15.6)$ & $1(2.2)$ & $3(6.6)$ \\
\hline Entamoeba histolytica \& Giardia lamblia & $5(5.6)$ & $1(2.2)$ & $0(0.0)$ \\
\hline Ascaris humbricoides & $2(2.2)$ & $0(0.0)$ & $0(0.0)$ \\
\hline Hymenolepis nana & $1(1.1)$ & $0(0.0)$ & $1(2.2)$ \\
\hline Entamoeba histolytica \& Ascaris humbricoides & $1(1.1)$ & $0(0.0)$ & $0(0.0)$ \\
\hline Dientamoeba fragilis & $1(1.1)$ & $0(0.0)$ & $0(0.0)$ \\
\hline
\end{tabular}

Table 7 shows the prevalence of intestinal parasitic infection was more reduced in females than males after application of hand washing technique.

Table7: The prevalence of parasitic infection between both sexes before and after hand washing intervention

\begin{tabular}{|l|l|l|l|l|}
\hline \multirow{2}{*}{ Variables } & \multicolumn{2}{|l|}{ Before (n=508) } & \multicolumn{2}{l|}{$\begin{array}{l}\text { After (n=45) } \\
\text { case }\end{array}$} \\
\cline { 2 - 5 } & \multicolumn{2}{|c|}{ N (\%) } & \multicolumn{2}{|c|}{ N (\%) } \\
\cline { 2 - 5 } & Male & Female & Male & Female \\
\hline $\begin{array}{l}\text { Washing children's hands with water after } \\
\text { defecation }\end{array}$ & $64(15.6)$ & $38(9.2)$ & $5(14.7)$ & $1(2.9)$ \\
\hline $\begin{array}{l}\text { Washing children's hands with water and } \\
\text { soap after defecation }\end{array}$ & $67(15.3)$ & $40(9.2)$ & $6(15.4)$ & $1(2.6)$ \\
\hline $\begin{array}{l}\text { Washing children's hands with water } \\
\text { before eating }\end{array}$ & $53(14.6)$ & $33(9.1)$ & $2(6.7)$ & $1(3.3)$ \\
\hline $\begin{array}{l}\text { Washing children's hands with water and } \\
\text { soap before eating }\end{array}$ & $55(14.0)$ & $40(10.2)$ & $3(8.6)$ & $1(2.9)$ \\
\hline
\end{tabular}

Table 8 shows that the prevalence of intestinal parasitic infection was decreased in age 10 and 11 but was absent in age 12 .

Table 8: The prevalence of intestinal parasitic infection before and after hand washing intervention between ages

\begin{tabular}{|c|c|c|c|c|c|c|c|c|}
\hline \multirow[t]{3}{*}{ Variables } & \multicolumn{4}{|c|}{ Before $(n=508)$} & \multicolumn{4}{|c|}{$\begin{array}{c}\text { After }(\mathrm{n}=45) \text { Intervention } \\
\text { Group }\end{array}$} \\
\hline & \multicolumn{4}{|c|}{$\begin{array}{c}\mathrm{N} \text { (Intestinal parasites) } \\
(\%)\end{array}$} & \multicolumn{4}{|c|}{$\begin{array}{c}\mathrm{N} \text { (Intestinal parasites) } \\
(\%)\end{array}$} \\
\hline & 9 & 10 & 11 & 12 & 9 & 10 & 11 & 12 \\
\hline $\begin{array}{l}\text { Washing children's hands } \\
\text { with water after defecation }\end{array}$ & $\begin{array}{l}16 \\
(3.9)\end{array}$ & $\begin{array}{l}26 \\
(6.3)\end{array}$ & $\begin{array}{l}45 \\
(10.9)\end{array}$ & $\begin{array}{l}15 \\
(3.6)\end{array}$ & $\begin{array}{l}2 \\
(5.9)\end{array}$ & $\begin{array}{l}1 \\
(2.9)\end{array}$ & $\begin{array}{l}3 \\
(8.8)\end{array}$ & $\begin{array}{l}0 \\
(0.0)\end{array}$ \\
\hline $\begin{array}{l}\text { Washing children's hands } \\
\text { with water and soap after } \\
\text { defecation }\end{array}$ & $\begin{array}{l}17 \\
(3.9)\end{array}$ & $\begin{array}{l}27 \\
(6.2)\end{array}$ & $\begin{array}{l}46 \\
(10.5)\end{array}$ & $\begin{array}{l}17 \\
(3.9)\end{array}$ & $\begin{array}{l}2 \\
(5.1)\end{array}$ & $\begin{array}{l}2 \\
(5.1)\end{array}$ & $\begin{array}{l}3 \\
(7.7)\end{array}$ & $\begin{array}{l}0 \\
(0.0)\end{array}$ \\
\hline $\begin{array}{l}\text { Washing children's hands } \\
\text { with water before eating }\end{array}$ & $\begin{array}{l}13 \\
(3.6)\end{array}$ & $\begin{array}{l}21 \\
(5.8)\end{array}$ & $\begin{array}{l}40 \\
(11.0)\end{array}$ & $\begin{array}{l}12 \\
(3.3)\end{array}$ & $\begin{array}{l}1 \\
(3.3)\end{array}$ & $\begin{array}{l}0 \\
(0.0)\end{array}$ & $\begin{array}{l}2 \\
(6.7)\end{array}$ & $\begin{array}{l}0 \\
(0.0)\end{array}$ \\
\hline $\begin{array}{l}\text { Washing children's hands } \\
\text { with water and soap before } \\
\text { eating }\end{array}$ & $\begin{array}{l}14 \\
(3.6)\end{array}$ & $\begin{array}{l}25 \\
(6.4)\end{array}$ & $\begin{array}{l}41 \\
(10.5)\end{array}$ & $\begin{array}{l}15 \\
(3.8)\end{array}$ & $\begin{array}{l}1 \\
(2.9)\end{array}$ & $\begin{array}{l}1 \\
(2.9)\end{array}$ & $\begin{array}{l}2 \\
(5.7)\end{array}$ & $\begin{array}{l}0 \\
(0.0)\end{array}$ \\
\hline
\end{tabular}




\section{4 | DISCUSSION}

The prevalence of intestinal parasites before hand washing intervention was $23.2 \%$, this result was similar to that reported by many authors in Gaza strip that the general prevalence of parasitic infection was $(28.9 \%)$ and $(24.5 \%),(8,10)$, The comparison of

the present findings with those from the neighboring countries such as Jordan (11) showed a considerable difference could be found in the overall prevalence of intestinal parasites (44\%). These differences can be explained by the influence of environmental conditions, hygiene, level of sanitation and differences in human behavior towards intestinal parasites and other risk factors.

It was found several types of parasites such as Entameoba histolytica/dispar, Giardia lamblia, Ascaris lumbricoides and Hymenolepis nana this results similar to previous studies carried out in Gaza strip (4).

The most common intestinal parasites detected in the present study were Entamoeba histolytica/dispar (73.3\%) followed by Giardia lamblia $(15.6 \%)$ before hand washing, compared to results reported by (Al Hindi and Al-Louh, 2013) who found that Entamoeba histolytica/dispar was $(22.9 \%)$ and Giardia lamblia was $(7.3 \%)$.

Most studies in Gaza strip reported Entamoeba histolytica/dispar and Giardia lamblia as the most common types (12).

According to the observation of the researchers no soap was seen in all schools toilets, so they depend only on water during hand washing intervention.

In the present study there was a clear decrease and reduction in the prevalence of intestinal parasitic infection among school children where it decreased from $23.2 \%$ to $15.5 \%$ after hand washing intervention, The decease of the prevalence rate of intestinal parasite was found to be statistically significant $\left(\mathrm{X}^{2}=4.265\right.$, $\mathrm{P}=0.02$ ).

For using only water after defecation, infection with intestinal parasites before hand washing was $20.1 \%$ but it decreased to $14.0 \%$ after hand washing intervention.

For using water and soap after defecation, infection with intestinal parasites before hand washing was $21.1 \%$ but it decreased to $16.3 \%$ after hand washing intervention, it was reported that the use of soap in hand washing is protective against Ascaris infection with respect to prevalence (13).

For using only water before eating, infection with intestinal parasites before hand washing was $16.9 \%$ but it decreased to $7.0 \%$ after hand washing intervention.

For using water and soap before eating, infection with intestinal parasite before hand washing was $18.7 \%$ but it decreased to $9.3 \%$ after hand washing intervention.

The post test study indicated that at the end of hand washing intervention there was deceases in Entamoeba histolytica/dispar (11.1\%) and Giardia lamblia (2.2\%), and there was noticed that no Ascaris infection present among children this may be explained by that the infected children have benefited for the practice of the hand washing after playing in sandy yards in addition there is more improvement in infrastruction.

In focusing group, during the study focusing group for mothers was done and this reflected on the reduction of parasitic infection among children.

The present work showed higher rates of parasitic infection among males $(61.0 \%)$ than females $(39.0 \%)$ this difference is statistically significant $(\mathrm{P}=0.004)$. Higher rates of infection among males are justify by that male spend their time in the streets, and playing in sand (14) but usually females tend to spend most of times in homes (15).

Through our study, we found that the infection of parasites for children from the age of 11 years is the highest proportion but it is not statistically significant $(\mathrm{p}=0.228)$.

In general, the prevalence of children that washing their hand was increased after learning hand washing technique, The proportion of children who wash their hands before eating and after defecation increased after education of hand washing technique.

The presence of intestinal parasites still found after health education may be due to several risk fac- 
tors such as, contamination of drinking water, Lack of commitment to children to wash their hands as learned or may be the reason children did not take treatment after the first infection.

\section{5 | CONCLUSION}

The problem of intestinal parasitic infection still exists in our society. The prevalence of intestinal parasite among school children from age 9 to 12 is 23.2\%. However, Entamoeba histolytica/dispar was the highest protozoa detected among school children in this study $(73.3 \%)$. Moreover, the prevalence of intestinal parasite among school children was reduced after application of hand washing technique and health education. In addition, the education level of the parents has a significant impact on children's awareness for personal hygiene especially hand washing.

The prevalence of intestinal parasites in male higher than female due to variant behavior of both sexes. Also, the most of children have symptoms (52.6\%) and the most children suffering from abdominal pain $(32.3 \%)$ but the least symptom was vomiting (7.3\%).

\section{6 | RECOMMENDATIONS}

Spreading of health ed-ucation among those children and their families. In addition, circulating the idea of hand washing tech-nique at the right way and distributed to all schools. Moreover, provision of soap and other hygiene in all schools.

\section{7 | ACKNOWLEDGEMENT}

The authors would to thanks Dr. Tyseer El-Shorafa and Mr. Mahmmoud Abu Samaan.

School Health department for their help during the approval of the study. We would also thank $\mathrm{Mr}$. Ahmed Selmi and Mr. Nasir al-Din Abu Shaban Medical Laboratory Sciences Department.

\section{REFERENCES}

1.Ejemot-Nwadiaro RI, Ehiri JE, Arikpo D, Meremikwu MM, \& Critchley, JA. (2020). Handwashing promotion for preventing diarrhoea. Cochrane database of systematic reviews 2020; (12).

2.Katz JD (2004). Hand washing and hand disinfection:: more than your mother taught you. Anesthesiology Clinics of North America 2014; 22(3), 457471 .

3. Okyay P, Ertug S, Gultekin B, Onen O, \& Beser E. Intestinal parasites prevalence and related factors in school children, a western city sample-Turkey. BMC public health 2004; 4(1), 1-6.

4.Abu-Mourad T. The impact of an environmental health and awareness programme on Palestinian refugees in Nuseirat Camp: A one-year-after report. Journal of Environmental Health Research 2006; $5(1), 37$.

5.Tomono N, Anantaphruti MT, Jongsuksuntigul P, Thongthien P, Leerapan P, Silapharatsamee Y\& Looareesuwan S. Risk factors of helminthiases among schoolchildren in southern Thailand. Southeast Asian journal of tropical medicine and public health 2003 ; 34(2), 264-268.

6.Al-Hindi A, Redwan A, El-egla G, Abu Qassem $\mathrm{R}$, Alshammari A. Prevalence of intestinal parasitic infections among university female students, Gaza, Palestine. Avicenna Journal of Medicine 2019; 9):4) 143-147.

7.Mezeid N, Shaldoum F, Al-Hindi A, Mohamed F, Darwish Z. Prevalence of intestinal parasites among the population of the Gaza Strip, Palestine. Annals of Parasitology 2014; 60(4), 281-289.

8.Kanoa B, George E, Abed Y, \& Al-Hindi A. Evaluation of the relationship between intestinal parasitic infection and health education among school children in Gaza city, Beit-lahia village and Jabalia refugee camp, Gaza strip, Palestine. The Islamic University Journal 2006; 14:2 .39-49, ISSN 17266807.

9.WHO. Bench aids for the diagnosis of intestinal parasites, World Health Organization, Geneva 2012.

10.Shubair ME, Yassin MM, Al-Hindi AI, AlWahaidi, AA, \& Jadallah, SY. Intestinal parasites in 


\section{MEERP LTD}

relation to haemoglobin level and nutritional status of school children in Gaza. Journal of the Egyptian Society of Parasitology 2000; 30(2), 365-375.

11.Jaran, AS. Prevalence and seasonal variation of human intestinal parasites in patients attending hospital with abdominal symptoms in northern Jordan. EMHJ-Eastern Mediterranean Health Journal 2106; 22 (10), 756 - 760. World Health Organization, Regional Office for the Eastern Mediterranean.

12.Alhindi A, Al-louh M. Trends of intestinal parasites prevalence in the Gaza Strip, 1998-2007: the use of government health records. Turkish Journal of Medical Sciences 2013; 43 (4), 652-659. DOI: 10.3906/sag-1208-86.

13.Fung IC, Cairncross S. Ascariasis and handwashing. Trans R Soc Trop Med Hyg. 2009; Mar103(3):215-22. doi: 10.1016/j.trstmh.2008.08.003. Epub 2008 Sep 11. PMID: 18789465.
14.Yassin MM, Shubair ME, Al-Hindi AI, \& Jadallah SY. Prevalence of intestinal parasites among school children in Gaza City, Gaza Strip. Journal of the Egyptian Society of Parasitology 1999; 29(2), 365-373.

15.Al-Wahaidi A. Effect of different sanitation conditions on the prevalence of infection with three types of intestinal parasites among the children in two localities in the Gaza strip. Palestine (thesis). University College London 1997.

How to cite this article: Alhindi A., Alkarirri M., Kanoa B., Ouda S.S.A., Erqyq Y.M., Radwan A.I., Jalambo M.O. Hand washing as an effective technique for intestinal parasites control among school children in Gaza city. Journal of Medical Research and Health Sciences. 2021;1557-1564. https://doi.org/10.52845/JMRHS/2021-4-11-7 